\title{
ARTYKUŁY
}

http://dx.doi.org/10.15762/ZH.2018.04

EDWARD WŁODARCZYK

(Uniwersytet Szczeciński)

\section{UWARUNKOWANIA EKONOMICZNEGO ROZWOJU MIAST PROWINCJI POMORSKIEJ W DWUDZIESTOLECIU MIĘDZYWOJENNYM}

Słowa kluczowe: Pomorze, miasta pomorskie, urbanizacja, życie gospodarcze, typologizacja miast

\section{UWAGI WSTĘPNE}

W dziejach prowincji pomorskiej okres dwudziestolecia międzywojennego charakteryzował się dużą dynamiką zmian. Pierwsza wojna światowa zmieniła bowiem sytuację geopolityczną i Pomorze Zachodnie stało się prowincją nadgraniczną ze wszystkimi tego skutkami. Dotyczyły one zarówno wydarzeń po 1918 r., jak i tych przed 1939 r. Najważniejsza zmiana dotyczyła położenia geopolitycznego wynikającego z odrodzenia się państwa polskiego, które z kolei realizowało określone cele polityczne przez politykę gospodarczą, celną czy taryf kolejowych. Należy zwrócić uwagę na to, że koła administracyjne prowincji oraz gospodarcze zaczęły widzieć różnice w interesach ekonomicznych poszczególnych części administracyjnych prowincji. Trzeba jednak podkreślić, że powstanie państwa polskiego tylko symbolicznie uszczupliło obszar prowincji pomorskiej (o jeden tysiąc hektarów), ale z drugiej strony zyskała ona kilka tysięcy hektarów z terytorium Prus Zachodnich ${ }^{1}$. W nowej sytuacji znalazły się również Niemcy. Ich zmieniona m.in. decyzjami wersalskimi sytuacja geopolityczna i ekonomiczna rzutowała na gospodarkę prowincji pomorskiej, przemiany społeczne i procesy urbanizacyjne. Zmiany graniczne i utworzenie państwa polskiego zaczęto w kołach gospodarczych prowincji pomorskiej krytycznie oceniać po upływie kilku lat, kierując się jednocześnie ar-

${ }^{1}$ Mieczysław Wojciechowski, Powrót Pomorza do Polski 1918-1920, Poznań 1963, passim. O problemach granicznych, zwłaszcza w kontekście Pomorza Gdańskiego, por. Stanisław SAlmonowicz, Podzialy terytorialne i organizacja administracji $w$ województwie pomorskim (1920-1939), [in:] Historia Pomorza, t. 5: (1918-1939). Województwo pomorskie i Wolne Miasto Gdańsk, cz. 1: Ustrój, społeczeństwo, gospodarka, red. Szczepan WierzchosŁawski, Przemysław Olstowski, Toruń 2015, s. 71-73. 
gumentami bardziej ideologiczno-politycznymi niż ekonomicznymi². Ponadto dla całego okresu dwudziestolecia w dziejach Pomorza Zachodniego można wyraźnie dostrzec cezurę wewnętrzną. W innych warunkach funkcjonowała gospodarka Pomorza oraz społeczeństwo w latach republiki weimarskiej i w innych w okresie III Rzeszy ${ }^{3}$.

W tym miejscu należy postawić pytanie: czy dla oceny procesów przemian w miastach należy zachować ich kategoryzację zaproponowaną dla drugiej połowy XIX stulecia i pierwszych lat XX w., czy też od niej odejść i podjąć próbę stworzenia nowej? Przypomnijmy, że dla okresu sprzed pierwszej wojny światowej wyróżnionych zostało pięć kategorii miast pomorskich: 1) miasta portowo-handlowe, 2) miasta średnie o charakterze komunikacyjno-handlowo-rzemieślniczym, 3) miasta średnie o charakterze administracyjno-rzemieślniczo-handlowym, 4) miasta średnie, które pełniły funkcje handlowe, rzemieślnicze i rolnicze, 5) miasta małe o charakterze handlowo-rzemieślniczo-rolniczym, zwane niekiedy w literaturze przedmiotu miastami karłowaty$\mathrm{mi}^{4}$. W rozważaniach o miastach prowincji pomorskiej powinniśmy brać pod uwagę nie tylko 73 miasta prowincji, jakie funkcjonowały na jej obszarze na początku okresu, lecz także włączone do niej w 1938 r. ośrodki miejskie rejencji pilskiej.

Chcąc w niniejszym artykule prześledzić specyfikę głównych uwarunkowań procesów demograficznych przez pryzmat ekonomicznego rozwoju miast, należałoby moim zdaniem skupić uwagę jednak tylko na 24 miastach (Anklam, Barth, Białogard, Bytów, Choszczno, Dąbie, Demmin, Goleniów, Greifswald, Gryfice, Kołobrzeg, Koszalin, Lębork, Pasewalk, Piła, Pyrzyce, Słupsk, Stargard, Stralsund, Szczecin, Szczecinek, Świnoujście, Trzebiatów i Wałcz), które możemy zaliczyć do trzech pierwszych kategorii. W kategorii pierwszej miast portowo-handlowych znalazły się: Szczecin, Stralsund, Greifswald, Barth, Świnoujście, Wolgast, Kołobrzeg, Darłowo i Ustka. Znaczenie tej ostatniej w dużym stopniu zależne było od sytuacji ekonomicznej Słupska. Do kategorii drugiej, tj. miast średnich o charakterze komunikacyjno-handlowo-rzemieślniczym (przemysłowym), zostały zaliczone: Stargard,

${ }^{2}$ Por. m.in. Edward WŁodarczyк, Wplyw zmian granicznych na wschodzie Niemiec po pierwszej wojnie światowej na gospodarkę prowincji nadgranicznych w ocenie Andreasa Hessego, Przegląd Zachodniopomorski (dalej cyt. PZP), R. 19 (48): 2004, nr 3, s. 47-58.

${ }_{3}^{3}$ Ogólne rozważania por. w rozprawach zawartych w: Pommern zwischen Zäsur und Kontinuität: 1918, 1933, 1945, 1989, hrsg. v. Bert Becker, Kyra T. InACHIN, Schwerin 1999.

${ }^{4}$ Edward WŁodarczyк, Tendencje rozwojowe miast prowincji (zachodnio)pomorskiej w latach 1850-1918, Zapiski Historyczne (dalej cyt. ZH), t. 63: 1998, z. 1, s. 94. Uwagi ogólne o typologizacji miast por. również w: Horst Matzerath, Urbanisierung in Preußen 1815-1914, Stuttgart 1985, s. 108, 138; Marjatta Hietala, Services and Urbanization at the Turn of Century. The Diffusion of Innovations (Studia Historica 23; Societas Historica Finlandiae), Helsinki 1987, s. 94-106. 
Pasewalk, Białogard, Szczecinek, Miastko i także z pewnymi zastrzeżeniami Słupsk. Ograniczone i specyficzne znaczenia komunikacyjne miały również Gryfice i Trzebiatów. Kategorię trzecią, tj. miast średnich o charakterze administracyjno-handlowo-rzemieślniczym (przemysłowym), stanowiły: Koszalin, Lębork, Anklam, Demmin i pozostałe miasta będące siedzibami starostw powiatowych. Zwraca uwagę fakt, że niektóre z tych ośrodków miejskich miały cechy pozwalające je zaliczyć zarówno do drugiej, jak i trzeciej kategorii. Z miast, które znalazły się na obszarze prowincji pomorskiej w 1938 r., Piła powinna być zaliczana do trzeciej kategorii. Decydowały tu zwłaszcza jej funkcje administracyjne, jednak pozostawała ona również ważnym węzłem komunikacyjnym, którego znaczenie rosło. Podobną sytuację miały Wałcz i Choszczno, chociaż w tych obu przypadkach odgrywały one tylko rolę siedzib władz powiatowych i tylko lokalnych węzłów komunikacyjnych. W zaproponowanych do rozważań 24 miastach niejako kumulowały się przemiany ekonomiczne w funkcji miast rzutującej na procesy demograficzne. Niektóre z miast zmieniły również swoje funkcje, tracąc dawny charakter i rozwijając inne obszary życia ekonomicznego. Warto jednocześnie zwrócić uwagę na procesy komunalizacji miast i rozbudowy infrastruktury komunalnej, co było przede wszystkim wyrazem postępu cywilizacyjnego. Za wydzieleniem grupy 24 miast przemawia także struktura zatrudnienia w przemyśle i rzemiośle w całej prowincji w 1930 r. W sektorze tym pracowało tylko 22,8\% ogółu zatrudnionych, podczas gdy średnia dla Rzeszy Niemieckiej wynosiła 41,4\%, w prowincjach graniczących z Pomorzem Zachodnim gorsze wskaźniki miały zaś tylko Marchia Graniczna (Grenzmark Posen-Westpreußen) (18,1\%) i Meklemburgia-Schwerin $(22,5 \%)^{5}$. Pozostałe średnie i mniejsze miasta prowincji pomorskiej utrzymywały charakter rolniczo-rzemieślniczy i w rozważaniach tych nie będą poddawane analizie.

\section{ROZWÓJ CZY STAGNACJA W LATACH 1919-1932?}

Sytuacja demograficzna miast pomorskich po pierwszej wojnie światowej była zróżnicowana i w dużym stopniu rzutowała na procesy ekonomiczne po zakończeniu działań zbrojnych. Należałoby się skłonić do tezy podnoszonej w starszej historiografii, że w okresie wojny duże miasta ponosiły znaczniejsze

${ }^{5}$ Statistisches Jahrbuch für das Deutsche Reich, Jg. 49: 1930, s. 23. Por. również: Donata voN Nerée, Industrie und Handwerk in Pommern in der Weimarer Republik - ein Überblick, [in:] Pommern. Geschichte - Kultur - Wissenschaft. Pommern im Reich und in Europa, hrsg. v. Horst Wernicke, Ralf-Gunnar Werlich, Greifswald 1996, s. 364-365. Genezę takiego położenia w kontekście procesów industrializacji Prus w XIX stuleciu pokazuje: Hubert KieseweTter, Industrialisierung und ausgebliebene Industrialisierung in Preußen, [in:] Pommern im 19. Jahrhundert. Staatliche und gesellschaftliche Entwicklung in vergleichender Perspektive, hrsg. v. Thomas Stamm-Kuhlmann, Köln 2007, s. 233-250. 
ciężary powszechnej mobilizacji i gospodarki wojennej niż mniejsze ośrod$\mathrm{ki}^{6}$. Taką tezę w pełni potwierdzała sytuacja ekonomiczna, a także zmiany na rynku pracy Szczecina i kilku innych miast pomorskich. Na wyjątkowo trudne położenie Kołobrzegu w okresie wojny i po jej zakończeniu uskarżały się jego władze. W czasie wojny działała tam fabryka amunicji zatrudniająca nawet do 3 tys. robotników. Ponadto w mieście zlokalizowano szpital wojskowy, w którym było 3600 łóżek. Na jego potrzeby zajmowano nawet niektóre hotele uzdrowiskowe. Wprawdzie po zakończeniu wojny ów lazaret został zlikwidowany, ale wielu jego pacjentów pozostało w mieście. Stąd skargi władz miasta na dużą liczbę bezrobotnych, która dochodziła do 2 tys. osób. Miasto nie było w stanie zapewnić odpowiednich warunków mieszkaniowych. Od 1919 do 1924 r. wybudowano tylko 67 domów z 336 mieszkaniami. Szpitale i lazarety wojskowe działały w czasie wojny również w kilku miastach pomorskich, w tym m.in. w Szczecinie, Koszalinie i Pasewalku .

W dwudziestoleciu międzywojennym miasta pomorskie w zasadzie nie powiększały swoich obszarów administracyjnych. Nie oznaczało to wcale, że procesy urbanizacyjne nie przekraczały ich granic. Miejski charakter utrzymywały dzielnice przemysłowe Szczecina, a jedna $\mathrm{z}$ nich - Podjuchy, pozostając gminą wiejską, przekroczyła w 1939 r. 10 tys. mieszkańców, dorównując kilku miastom powiatowym. W odniesieniu tylko do dwóch miast można mówić o rozszerzeniu ich granic w 1939 r. Najpierw w kwietniu 1939 r. decyzją nadprezydenta prowincji do Greifswaldu włączone zostały gminy Wieck i Eldena. W październiku 1939 r. zaś decyzją rządu pruskiego utworzony został tzw. wielki Szczecin (Groß-Stettin), którego liczba ludności wzrosła wówczas do ponad 380 tys. i wchłonął on oprócz kilku gmin wiejskich dwa samodzielne miasta, mianowicie Dąbie i Police ${ }^{8}$.

Po zakończeniu wojny miasta pomorskie dążyły raczej do zachowania swojego potencjału ekonomicznego, głównie przemysłowego, niż do jego rozbudowy. W dużym stopniu rzutowało to na procesy demograficzne.

Niemal przez całe dwudziestolecie w handlu morskim podejmowane były starania, aby port szczeciński osiągnął wielkość przeładunków sprzed wojny. W 1926 r. wynosiły one 5,8 mln ton, co stanowiło 93\% wielkości obrotów

\footnotetext{
${ }^{6}$ Jürgen Reulecke, Städtische Finanzprobleme und Kriegswohlfahrtspflege im Ersten Weltkrieg unter besonderer Berücksichtigung der Stadt Barmen, Zeitschrift für Stadtgeschichte, Stadtsoziologie und Denkmalpflege, Jg. 2: 1975, Nr. 1, s. 48-80; Hans Моттек, Walter BeCKeR, Alfred Schrötter, Wirtschaftsgeschichte Deutschlands. Ein Grundriß, Bd. 3, Berlin 1975, s. 204.

${ }^{7}$ Bundesarchiv Berlin (dalej cyt. BA Berlin), Reichsministerium des Innern. Kommunalabteilung, Nr. 1699, s. 38-39.

${ }^{8}$ Mieczysław Stelmach, Geneza „wielkiego Szczecina”, [in:] Dzieje Szczecina, t. 3: 18061945, red. Bogdan Wachowiak, Szczecin 1994, s. 527 n.; Joachim MaI, Die Jahre der Weimarer Republik und der nationalsozialistischen Diktatur, [in:] Greifswald. Geschichte der Stadt, hrsg. v. Horst Wernicke, Schwerin 2000, s. 130.
} 
sprzed wojny. Dopiero w 1936 r. przekroczyły one $8,3 \mathrm{mln}$ ton i były nieznacznie większe niż w 1913 r. W kolejnych latach, tj. 1937 i 1938 r., przeładunki w porcie przekraczały $8 \mathrm{mln}$ ton, ale były nieco niższe niż w $1936 \mathrm{r} .{ }^{9} \mathrm{Na}$ sytuację portu wpływało wiele czynników. Władze administracyjne prowincji, a także koła gospodarcze (choć te ostatnie dopiero od połowy lat dwudziestych) zaczęły powtarzać argument, że najważniejszym z nich stawała się utrata zaplecza portu, które weszło w skład państwa polskiego. Port szczeciński przez cały okres dwudziestolecia międzywojennego prowadził ostrą walkę konkurencyjną z portami polskiego obszaru celnego i wielokrotnie tę rywalizację przegrywał. Oprócz trudnej walki konkurencyjnej z portami polskiego obszaru celnego port szczeciński nadal konkurował z portem hamburskim. Nawet w obsłudze niemieckiego handlu bałtyckiego, zwłaszcza w wywozie, Hamburg znacznie wyprzedzał obroty Szczecina (w 1925 r. Szczecin obsługiwał 37\%, a Hamburg 51\% ogółu obrotów niemieckich na Bałtyku). W przywozie te różnice nie były tak znaczne, ale przewaga Hamburga była także widoczna.

Wielkość obrotów towarowych pozostałych portów zachodniopomorskich była wręcz symboliczna. W połowie lat dwudziestych pięć z nich, tj. Kołobrzeg, Ustka, Darłowo, Saßnitz i Stralsund, przeładowywało niewiele ponad 300 tys. ton. W 1930 r. wielkość ta nie przekraczała jednego mln ton. Porty rejencji koszalińskiej w 1933 r. przeładowywały wręcz symboliczne wielkości towarów: Kołobrzeg - 136 tys. ton, Darłowo 26,5 tys. ton, Ustka zaś niespełna 20 tys. ton. Obsługiwały one tylko najbliższe zaplecze, które geograficznie odnosiło się do własnej prowincji ${ }^{10}$. Stąd ich przynależność do kategorii miast portowo-handlowych stawała się niemal symboliczna i mocno dyskusyjna.

Przemysł szczeciński po pierwszej wojnie światowej znalazł się na marginesie niemieckiej gospodarki. Szczecińskie spółki przemysłowe, mimo zaangażowanego w nie kapitału z innych regionów Niemiec, nie weszły do nowych organizacji gospodarczych, zwłaszcza łączących przedsiębiorstwa branży metalurgicznej, stoczniowej czy maszynowej. W okresie dwudziestolecia międzywojennego Szczecin przestawał być wiodącym ośrodkiem przemysłu stoczniowego. Wskutek konkurencji hambursko-bremeńskiego koncernu „Deschimag”, wynikającej głównie z kurczącego się portfela zamówień, w latach 1927-1931 zlikwidowane zostały szczecińskie stocznie Vulcan, Ostseewerft i zakład Nüsckego. Poważnie ograniczyła swoją produkcję inna stocznia - Stettiner Oderwerke.

${ }^{9}$ Szerokie rozważania o rozwoju szczecińskiego handlu morskiego prowadzili m.in.: Bogdan DopieraŁA, Kryzys gospodarki morskiej Szczecina 1919-1939, Poznań 1963; Edward WŁodarczyк, Życie gospodarcze, [in:] Dzieje Szczecina, t. 3, s. 568-684.

${ }^{10}$ BA Berlin, Reichswirtschaftsministerium, Nr. 9752, s. 237. Szerzej por. Edward WŁODARCZYK, Handel morski i porty Pomorza Zachodniego w pierwszych latach II wojny światowej, ZH, t. 55: 1990, nr 2-3, s. 17-39. 
Od połowy lat dwudziestych władze prowincji lub rejencji, przedstawiciele różnych organizacji gospodarczych, widząc załamanie gospodarki miast pomorskich, zaczęli wskazywać na główne, ich zdaniem, źródło regresu ekonomicznego, mianowicie zmiany granic po zakończeniu pierwszej wojny światowej i pozbawienie możliwości zbytu towarów produkowanych przez miejscowe zakłady na ziemiach polskich. Palmę pierwszeństwa w postawieniu takiej diagnozy przyznaje się prezesowi rejencji koszalińskiej Kurtowi Cronauowi. Wystąpił on z memoriałem, w którym wymieniał wiele negatywnych aspektów dla gospodarki wschodniej części Pomorza po ustanowieniu granicy polsko-niemieckiej. Wskazał m.in. na znaczny przyrost ludności w miastach pomorskich w okresie od 1919 do 1926 r. wskutek napływu do obszaru prowincji tzw. optantów. Cronau wymienił Lębork jako miasto, którego ludność wzrosła o ponad $25 \%$. Wysoki wskaźnik przyrostu mieszkańców miały także: Miastko (14\%), Słupsk (11,8\%), Łeba (12\%) i Bytów (prawie 6\%) ${ }^{11}$.

Ocena procesów demograficznych przez Cronaua budzi jednak pewne zastrzeżenia. Przede wszystkim w momencie powstawania jego memoriału (z datowaniem go są pewne problemy, chociaż przyjmuję, że powstał on w 1926 r.) sytuacja demograficzna rejencji wyglądała nieco inaczej. Trzy największe miasta rejencji, tj. Słupsk, Kołobrzeg i Koszalin, w latach 1925-1933 notowały przyrost demograficzny, ale wynikał on zarówno z przyrostu naturalnego, jak i migracyjnego. Koszalin odnotował wzrost ludności o 5,47\%, z czego 2,45\% stanowił przyrost naturalny i 3,02\% przyrost imigracyjny. Kołobrzeg i Słupsk miały większy przyrost liczby mieszkańców i znaczniejszy w nim udział ludności napływowej. Kołobrzeg odpowiednio od 3,05\% do 8,89\%, co dawało przyrost ogólny rzędu 11,94\%, Słupsk zaś od 3,32\% do 5,60\%, co oznaczało wzrost o 8,92\%. W tych rozważaniach dotyczących okresu 1925-1933 warto odnieść się jeszcze do niektórych powiatów rejencji. Widoczna tu była bowiem pewna zasada. We wszystkich powiatach wysoki był przyrost naturalny (od 5,84\% do 9,70\%) i jednocześnie widoczna była tendencja znacznego odpływu ludności wskutek procesów migracyjnych. Dodatni bilans tych ruchów migracyjnych odnotowywały powiaty, które miały większe miasta ze stosunkowo dobrze prosperującą gospodarką (Lębork, Białogard, Drawsko, Miastko) ${ }^{12}$. Argumentacja Cronaua była niekonsekwentna. Najlepiej oddają to informa-

${ }^{11}$ Vorpommersches Landesarchiv Greifswald (dalej cyt. LA Greifswald), Rep. 60, Nr. 1915, s. 155-162. Tekst memoriału K. Cronaua publikowali także: Bogdan DopieraŁa, Ekonomiczne i demograficzne problemy Pomorza Zachodniego w świetle niemieckich materiałów źródłowych z lat 1926-1932, Poznań 1959, s. 232-244; Edward WŁodarczyк, Pomorze Zachodnie w okresie od traktatu wersalskiego po klęskę III Rzeszy w 1945 roku (Źródła do kaszubsko-polskich aspektów dziejów Pomorza Zachodniego do 1945 roku, t. 4), Poznań-Gdańsk 2006, s. 121-129.

${ }^{12}$ BA Berlin, Reichswirtschaftsministerium, Nr. 9755, s. 23 (inserowane opracowanie: Bruno Heinemann, Ostpommern. Bedeutung und Aufgabe, Stolp 1936). 
cje przytoczone przez syndyka Izby Przemysłowo-Handlowej dla rejencji koszalińskiej Sieversa skonfrontowane z innymi miastami i powiatami prowincji oraz z okresem poprzednim. W 1926 r. prowincja pomorska straciła w stosunku do 1919 r. w ogólnym bilansie migracyjnym tylko 1,3\% ludności, przy czym największy ubytek miała jednak rejencja stralsundzka (strzałowska) - 5,1\%, podczas gdy rejencja koszalińska straciła tylko 3,7\% ludności. Swoistym rekordzistą był jednak powiat miejski greifswaldzki (gryfijski), z którego wyemigrowało ponad 7 tys. osób, co stanowiło $21,1 \%$ ogółu ludności. Wynikało to zapewne z trudnej sytuacji ekonomicznej miasta i zamknięcia kilku zakładów głównie branży metalowej i maszynowej. Okoliczności te przeczyły także zasadzie, że powiat miejski i powiaty okoliczne, takie jak w przypadku Szczecina gryfiński, randowski, a nawet nowogardzki, „korzystały” z potencjału wielkiej aglomeracji miejskiej. W tych rozważaniach dotyczących zmian demograficznych w miastach do połowy lat dwudziestych powinniśmy jeszcze uwzględnić odmienną sytuację w Bytowie. Miasto bowiem przyjmowało największą liczbę tzw. optantów. W latach 1919-1925 stanowili oni grupę licząca ok. 225-230 osób. W 1926 r. przybyły kolejne grupy optantów. Tylko w ciągu półtora roku od początku 1925 do czerwca 1926 r. zjawiło się 550 osób zaliczanych do tej grupy. Stawali się oni problemem miasta nie tylko demograficznym i ekonomicznym, lecz także politycznym ${ }^{13}$.

Analizując sytuacje większych miast pomorskich, zauważamy, że w latach 1919-1925 poza Greifswaldem wszystkie zanotowały dodatni bilans migracyjny, który w przypadku Słupska wyrażał się wzrostem o 6,8\%, Stargardu o $12,3 \%$, Stralsundu o 8,3\% i Szczecina o 7,6\%. Z miast pomorskich, dla których bilans migracyjny rozliczano w skali powiatu za okres 1919-1925, dodatnie saldo miały ponadto Białogard (1,6\%), Drawsko Pomorskie (0,5\%), Gryfino (1,5\%), Nowogard (3,0\%), Pyrzyce $(1,2 \%)$, powiat randowski $(2,9 \%)$, powiat rugijski (2,2\%), wkryujski (Ückermünde) (2,5\%), uznamsko-woliński (12,0\%). W następnym okresie spisowym, za lata 1926-1933, duże miasta pomorskie notowały dodatni bilans ruchów migracyjnych od najniższego w Szczecinie wynoszącego 2,9\% do najwyższego w Kołobrzegu wynoszącego 9\%. Zauważyć należy, że również w Greifswaldzie po zapaści z poprzedniego okresu nastąpił wzrost o $8,2 \%{ }^{14}$.

${ }^{13}$ Dariusz Szudra, Ludność pruskiej prowincji Pomorze. Przemiany w ruchu naturalnym i migracyjnym w latach 1914-1939, Szczecin 2005, s. 102 n.; Józef Lindmajer, Bytów w okresie republiki weimarskiej i rządów faszystowskich (1918-1945), [in:] Historia Bytowa, red. Zygmunt SzultKa, Bytów 1998, s. 300.

${ }^{14}$ Szersze rozważania na ten temat prowadził Dariusz Szudra, zob. op.cit., s. 240-247; por. również: Wirtschafts- und verkehrsgeographischer Atlas von Pommern, hrsg. v. Werner WITT, Stettin 1934, s. 25 n. 
Alarmujące fakty podane przez Cronaua dotyczące zmniejszania się potencjału ekonomicznego miast, co z kolei skutkowało wzrostem bezrobocia, potwierdzane były przez koła gospodarcze. I tak w Lęborku przed wybuchem wojny czynnych zawodowo było prawie 4100 osób przy 19 tys. mieszkańców. Po zakończeniu wojny liczba ich spadła do 3 tys. osób. Po zakończeniu wojny tylko fabryka zapałek musiała zwolnić 450 osób. Podobne zwolnienia następowały w Sianowie (także produkowano tam zapałki). Ograniczano również liczbę zatrudnionych w papierniach w Koszalinie i Warcinie. W Lęborku w 1933 r. zanotowano 3350 bezrobotnych. Ograniczone możliwości produkcyjne fabryk w rejencji koszalińskiej prowadziły do kurczenia się miejscowej produkcji. Taka sytuacja wystąpiła m.in. w Kaliszu Pomorskim, Szczecinku, Bytowie czy Karlinie. Spadek produkcji prowadził z kolei do emigracji z miast pomorskich robotników wysoko wykwalifikowanych ${ }^{15}$. Władze rejencji chętnie posługiwały się określeniem jej jako „półwyspu niemieckiego oblanego polskim żywiołem", domagając się przez tego rodzaju argument specjalnych przywilejów dla poszczególnych dziedzin życia gospodarczego i postulując objęciem rejencji akcją Osthilfe. Należy jednak pamiętać, że zaangażowanie, nawet częściowe, państwa pruskiego w gospodarkę prowincji nie zawsze przynosiło pozytywne efekty. Taka sytuacja miała miejsce w przypadku Szczecińsko-Pruskiej Wspólnoty Portowej powstałej w 1923 r., z której rząd pruski praktycznie wycofał się w 1929 r., zawierając podobny układ z Hamburgiem ${ }^{16}$.

W 1929 r. w miastach rejencji koszalińskiej funkcjonowało 270 zakładów przemysłowych. Największa ich liczba występowała w Słupsku - 62, Kołobrzegu - 43, Koszalinie 25, Lęborku 24 oraz Szczecinku i Świdwinie - po 18. Zwraca uwagę natomiast „rozłożenie” geograficznego handlu hurtowego. Taką działalność prowadziło łącznie 358 firm handlowych. Najważniejszym jego ośrodkiem ponownie był Słupsk - 73, potem zaś Koszalin - 38, Kołobrzeg 35, Lębork - 29, Szczecinek - 23 oraz Bytów - $18^{17}$.

Stagnacja, a nawet regres życia gospodarczego w latach dwudziestych $\mathrm{w}$ miastach pomorskich był zjawiskiem niemal powszechnym. Prasa dosyć często informowała o zwolnieniach robotników w stosunkowo dużych, ale przeżywających kryzys zakładach przemysłowych. W listopadzie 1927 r. zwolniono ok. 300 robotników w zasłużonej dla armii niemieckiej fabryce szczecińskiej Auto-Stoewer Werke. W 1928 r. przewidywano zwolnienia w przemy-

${ }^{15}$ LA Greifswald, nr 1917, s. 113-116 (inserowane opracowanie syndyka Izby Przemysłowo-Handlowej rejencji koszalińskiej Sieversa: Die Gebietsverluste im Osten. Handel und Industrie im Regierunsbezirk Köslin); BA Berlin, Reichswirtschaftsministerium, Nr. 9755, s. 51.

${ }^{16}$ Edward WŁodarczy , Powstanie Szczecińsko-Pruskiej Wspólnoty Portowej w 1923 roku, PZP, R. 7 (46): 1992, nr 3, s. 29-47.

${ }^{17}$ Kacper Pencarski, „Gospodarka miast rejencji koszalińskiej w latach 1918-1939”, Słupsk 2012 (maszynopis rozprawy doktorskiej w bibliotece Akademii Pomorskiej), s. 351. 
śle stoczniowym tysięcy robotników. Nadprezydent prowincji w tym samym roku apelował do Pruskiego Ministra Spraw Wewnętrznych o uruchomienie pomocy mieszkańcom podszczecińskiego Golęcina, który w zdecydowanej większości zamieszkiwali robotnicy i ich rodziny. W tym samym czasie w Słupsku zwolniono w budownictwie ok. 150 robotników. Fabryka filcu z Gryfina wymówiła pracę 200 osobom. Kilkadziesiąt osób zwolniono z warsztatów szczecińskiego lotniska. W Greifswaldzie w drugiej połowie lat dwudziestych bez pracy pozostawało 600 osób. Wcześniej pracowali oni w przemyśle maszynowym oraz w warsztatach naprawczych na kolei ${ }^{18}$. Możemy w tym miejscu postawić tezę, że załamanie gospodarcze wielu miast pomorskich nastąpiło jeszcze przed kryzysem światowym.

Akcentując załamanie się w wielu miastach pomorskich produkcji przemysłowej, należy także dostrzec fabryki, które potrafiły utrzymywać dobre wyniki produkcyjne. Dotyczyło to głównie stolicy prowincji Szczecina. Ciekawie rozwijał się tutaj zakład J. Gollnowa specjalizujący się w budowie mostów i hal fabrycznych. Otrzymywał on sporo zamówień zagranicznych, w tym przez kilka lat ze Związku Sowieckiego.

Przestawienie gospodarki niemieckiej po przejęciu władzy przez partię narodowosocjalistyczną na zbrojenia dało podstawy do rozbudowy huty „Kraft” w Szczecinie i do zwiększenia jej mocy produkcyjnej. W Szczecinie nadal dobrze funkcjonowały cementownie. Weszły one do kartelu „Norddeutscher Zementverband", który wprawdzie limitował wielkość produkcji, ale zapewniał ciągłość zamówień. To pozwalało Szczecinowi utrzymywać, mimo kryzysu i niemal całkowitego załamania się produkcji stoczniowej, rolę wiodącego ośrodka przemysłowego prowincji.

Przed pierwszą wojną światową dynamicznie rozwijały się miasta zaliczone do kategorii ważnych ośrodków komunikacyjnych (Stargard, Pasewalk). Po zakończeniu wojny nasycenie liniami kolejowymi Pomorza było wystarczające i nowe linie kolejowe otwierano sporadycznie. W 1921 r. uruchomione zostało połączenie między Polanowem a Korzybiem, w 1934 r. zaś otwarto linię Sławno-Polanów-Żydowo. Władze rejencji koszalińskiej postulowały, w niektórych wypadkach skutecznie, poprawę połączeń między poszczególnymi miastami. Dotyczyło to połączenia Koszalina z Piłą czy połączeń Piły ze Słupskiem, Kołobrzegiem i Połczynem-Zdrój. Okręgowa Dyrekcja Kolei w Szczecinie miała natomiast zastrzeżenia do nierentowności niektórych połączeń kolejowych na trasach dalekobieżnych, łączących przykładowo Kołobrzeg z Poznaniem czy Wrocławiem. Do rangi ważnych ośrodków komunika-

${ }^{18}$ LA Greifswald, Rep. 60, Nr. 1917, s. 29, 68, 73; Rep. 60, Nr. 2007, s. 81, 97, 127; Volksbote, Nr. 266 z 12 XI 1927 r.; Volkswacht für Stettin und Provinz Pommern, Nr. 16 z 19 I 1928 r.; General-Anzeiger, Nr. 353 z 21 XII 1926 r.; J. MAI, op.cit., s. 125. 
cyjnych powinny były awansować wówczas te miasta, z których linie kolejowe wybiegały w czterech lub pięciu kierunkach. Połączenia w pięciu kierunkach miały: Szczecin, Stralsund, Stargard, Białogard, Szczecinek, Pasewalk, Koszalin i Słupsk. W początkach lat dwudziestych dołączyły do tej kategorii Sławno i Lębork. Natomiast Grimmen, Pyrzyce, Kalisz Pomorski, Złocieniec, Płoty i Tribsee były węzłami dla czterech linii kolejowych. Po 1938 r., tj. po rozszerzeniu granic prowincji, do grupy miast mających połączenia $\mathrm{w}$ czterech kierunkach należy zaliczyć również Piłę, która zwłaszcza w połączeniach z ziemiami polskimi odgrywała ważną rolę ${ }^{19}$. Ruch towarów na trasach kolejowych w latach dwudziestych był wzmożony mimo niezbyt dobrej koniunktury gospodarczej. Już w 1924 r. w większych miastach rejencji koszalińskiej przeładunki towarów były wyższe niż w 1914 r. Przed wybuchem kryzysu światowego w Kołobrzegu przeładowywano 224 tys. ton, tj. o 105 tys. ton więcej niż w 1924 r., w Koszalinie 218 tys. ton, tj. o 99 tys. więcej niż w 1924 r., w Słupsku 463 tys. ton, tj. o 170 tys. ton więcej niż w 1924 r. Wysokie przeładunki notowały także Białogard (116 tys. ton), Szczecinek (112 tys. ton) i Lębork (107 tys. ton $)^{20}$. Można zatem stwierdzić, że kolej pozytywnie wpływała na gospodarkę wielu miast pomorskich, nie tylko tych, które w XIX stuleciu były ważnymi węzłami komunikacyjnymi.

Miasta pomorskie będące $\mathrm{w}$ dużej mierze ośrodkami handlu regionalnego lub nawet lokalnego powinny były szczególną troskę przywiązywać do połączeń z tym rynkiem lokalnym. Takie założenia najlepiej mogły zrealizować przez rozwój sieci kolejek wąskotorowych, w którą Pomorze zostało już mocno nasycone przed wybuchem pierwszej wojny światowej. Okazuje się jednak, że zainteresowanie miast takimi połączeniami i działalnością spółek akcyjnych, które owe koleje wąskotorowe eksploatowały, było ograniczone i zróżnicowane nie tylko regionalnie, lecz także czasowo. W rejencji koszalińskiej miasta nie były specjalnie zainteresowane finansowo działalnością dominujących spółek kolejek wąskotorowych. I tak obsługująca głównie obszar powiatu kołobrzesko-karlińskiego Kołobrzeska Kolej Wąskotorowa (Kolberger Kleinbahn A.G.) finansowana była przez prowincję pomorską, państwo pruskie, landrata powiatu oraz firmy prywatne i właścicieli ziemskich. Kolej ta zbudowała połączenia z siecią kolejek w Resku i Gryficach. Podobnie, czyli bez udziału finansowego miasta, działała łącząca Sławno z jego lokalnym rynkiem Sławieńska Kolej Wąskotorowa (Schlawer Kleinbahn A.G.). Towarzystwo akcyjne, które eksploatowało połączone kolejki w powiatach koszalińskim, bobolickim i białogardzkim (AG der Vereinigten Kleinbahnen der Kreise Köslin,

${ }^{19}$ Andrzej Mielcarek, Transport drogowy, wodny i kolejowy w gospodarce prowincji pomorskiej w latach 1815-1914, Szczecin 2000, s. 103-104.

${ }^{20}$ K. PencARSKI, „Gospodarka miast rejencji”, s. 139-149. Uwagi ogólne o liniach kolejowych na Pomorzu por. w: A. MielCareK, op.cit., s. 156 n. 
Bublitz und Belgard), także obywało się bez kapitału pochodzącego od kół gospodarczych z tych miast. Sytuacja taka powtarzała się w Słupsku z Koleją Wąskotorową Doliny Słupi (Stolpetalbahn). Natomiast Szadzka Kolej Wąskotorowa (Saatziger Kleinbahn A.G.) działająca na obszarze powiatu szadzkiego (stargardzkiego) miała spory (19\%) udział miasta Stargardu ${ }^{21}$. Można w tym miejscu postawić tylko pytanie o potencjał finansowy kół gospodarczych wspomnianych miast. Brak zainteresowania kolejami wąskotorowymi wynikał, w mojej ocenie, w dużej mierze z ich słabości kapitałowej.

Sytuacja zmieniła się po 1933 r. W 1939 r. prowincja dysponowała 1651 km linii wąskotorowych. W towarzystwach tych linii było zaangażowanych ponad 35 mln marek kapitału, który w większości należał do powiatów (16,5 mln marek), prowincji (9,5 mln marek) i państwa pruskiego (7,6 mln marek). Miasta pomorskie zaangażowały jednak łącznie ok. 1 mln marek. Akcje kolejek wąskotorowych miały: Stralsund, Greifswald, Stargard, Kołobrzeg (te dwa ostatnie miasta m.in. w Południowo-Franzburskiej Kolei Wąskotorowej; Franzburger Südbahn), Nowe Warpno, Gryfice, Trzebiatów, Resko, Białogard, Lębork i Szczecin. Dla linii wąskotorowych najważniejszymi węzłami stawały się: Anklam (cztery linie) oraz Trzebiatów, Gryfice i Jarmen (po trzy linie). Zainteresowanie miast, w tym także tych $\mathrm{z}$ rejencji koszalińskiej, kolejami wąskotorowymi z jednej strony świadczyło o docenieniu ich wagi w rozwoju handlu lokalnego i nawet ponadregionalnego, z drugiej zaś wynikało zapewne z nacisków politycznych. Do takiego wniosku skłania pismo Gauleitera F. Schwede-Coburga do Deutsche Reichsbahngesellschaft z grudnia 1935 r., w którym wyrażał on zaniepokojenie słabym tętnem życia gospodarczego w niektórych powiatach $^{22}$. Kolej pozostawała na Pomorzu najważniejszym przewoźnikiem towarów z uwagi na słabość żeglugi śródlądowej. W tym względzie poza Szczecinem do rangi ośrodka żeglugi śródlądowej przewożącego większą ilość towarów mógł być zaliczany tylko Anklam. W innych przypadkach (np. przewozy do Darłowa na Wieprzy czy do Ustki na Słupi) należałoby zaliczać do śladowych ${ }^{23}$.

Jednym z bardziej istotnych elementów procesu urbanizacji nie tylko miast pomorskich, lecz także ich postępu cywilizacyjnego stawał się rozwój infrastruktury komunalnej. Poprawiała ona zdecydowanie warunki życia w miastach. Niekiedy zasięg infrastruktury komunalnej przekraczał granice miasta,

${ }^{21}$ K. PenCARski, „Gospodarka miast rejencji”, s. 159-166.

${ }^{22}$ BA Berlin, Reichsministerium des Innern. Kommunalabteilung, Nr. 4171, s. 469-103; Reichsministerium des Innern. Kommunalabteilung, Nr. 4166, s. 49-50; Rechnungshof des Deutschen Reiches, Nr. 6202, s. 35, 44; A. MielCarek, op.cit., s. 104.

${ }^{23}$ Józef Lindmajer, Przyczynek do monografii gospodarczej matych rzek Pomorza Zachodniego na przykładzie Wieprzy w trzecim ćwierćwieczu XIX stulecia, Rocznik Koszaliński, nr 35: 1997, s. 35-53. 
przenosząc poprawę warunków mieszkaniowych również na osiedla podmiejskie. Dotyczyło to głównie Szczecina. Tworzenie infrastruktury komunalnej w większości miast pomorskich przypadało na drugą połowę XIX stulecia i pierwsze lata przed wybuchem wojny. Tempo komunalizacji miast było jednak nierówne. Szybciej te procesy przebiegały w miastach dużych, głównie w Szczecinie, wolniej zaś w miastach mniejszych, a w niektórych z nich zaliczanych do kategorii miast karłowatych widoczne stawało się ich duże zapóźnienie.

Miasta pomorskie dość szybko zaczęły budowę sieci gazowej i wodociągowej. Szczecin gazownie uruchomił jeszcze w $1847 \mathrm{r}$. W $1858 \mathrm{r}$. gazownia otwarta została w Greifswaldzie, a potem kolejno w Kołobrzegu, Koszalinie i Słupsku. Z miast pomorskich najdłuższą sieć gazową miał Szczecin. Trzy kolejne miasta pomorskie (Stargard, Słupsk i Stralsund) miały łącznie kilkukrotnie krótszą sieć przesyłową gazu niż stolica prowincji. Zaopatrzenie w gaz w miastach pomorskich przed $1914 \mathrm{r}$. stało na znacznie niższym poziomie niż w miastach wielkopolskich. Bardziej skomplikowana pod względem technicznym, jak i finansowym, była sprawa budowy sieci wodociągowej. Przed pierwszą wojną światową nie wszystkie miasta pomorskie potrafiły zapewnić swoim mieszkańcom wodę dostarczaną przez miejskie wodociągi ${ }^{24}$.

Ciekawie wyglądała sytuacja elektryfikacji miast pomorskich. Z jednej strony miała ona ogromne znaczenie dla ich rozwoju gospodarczego i zastępowania $\mathrm{w}$ przemyśle napędu parowego elektrycznym, $\mathrm{z}$ drugiej zaś energia elektryczna dawała możliwość oświetlania miasta, mieszkan i wykorzystania jej do rozwoju komunikacji tramwajowej w większych miastach. Sprawy związane z elektryfikacją i produkcją energii elektrycznej państwo pruskie przed pierwszą wojna światową pozostawiło samorządom i inwestorom prywatnym. Przed wybuchem wojny do sieci energetycznej przyłączone było na Pomorzu prawie dwa tysiące jednostek komunalnych (miasta, gminy, okręgi dworskie), w tym 44 z 73 miast pomorskich. Procesu elektryfikacji nie przerwano w pierwszych latach wojny. Po jej zakończeniu prowincję pomorską w energię elektryczną zaopatrywało pięć zakładów energetycznych (Słupsk, Białogard, Maszewo, Szczecin i Stralsund) dysponujących siecią przesyłową o długości 10,7 tys. km. Zaznaczyć trzeba, że zakłady energetyczne nabywały energię produkowaną przez wytwórców miejscowych i niekiedy działających poza granicami prowincji. W $1925 \mathrm{r}$. działające dotychczas zakłady energetyczne po-

${ }^{24}$ Edward WŁodarczyK, Rozwój urbanistyczny miast pomorskich i ich gospodarka komunalna, [in:] Historia Pomorza, t. 4: (1850-1918), cz. 1: Ustrój, gospodarka, społeczeństwo, red. Stanisław Salmonowicz, Toruń 2000, s. 468 n.; Franz Scherer, Stadtgeschichte von 1815 bis 1918, [in:] Greifswald. Geschichte der Stadt, s. 119. Uwagi ogólne o rozwoju gazownictwa w Wielkopolsce zob. w: Miron Urbaniak, Miejskie zakłady przemysłowe Wielkiego Księstwa Poznańskiego. Gazownie, t. 1: Zarys dziejów, Łódź 2011. 
łączono w jeden z siedzibą w Szczecinie (Überlandzentrale Pommern A.G.). W 1924 r. wszystkie miasta pomorskie, podobnie jak prawie 1700 gmin wiejskich i prawie 2,8 tys. okręgów dworskich, włączone zostały do sieci energetycznej. Rok później energia elektryczna z centrali szczecińskiej docierała do 85 miast (niektóre z nich leżały poza granicami prowincji, jak przykładowo Wałcz i Myślibórz). W 1932 r. energia elektryczna z Zakładu Energetycznego Pomorze trafiała do 95 miast, 2769 majątków ziemskich, 782 dużych zakładów przemysłowych ${ }^{25}$. Centralna dystrybucja energii była możliwa przez cztery oddziały zakładu energetycznego (Stralsund, Maszewo, Białogard i Słupsk), w których działało kilka elektrowni produkujących energię na bazie węgla. Na obszarze rejencji koszalińskiej korzystano w stosunkowo szerokim stopniu także z elektrowni wodnych. Do prowincji pomorskiej dostarczana była również energia produkowana poza jej granicami. Najpoważniejszym dostawcą był Marchijski Zakład Energetyczny (Märkisches Elektrizitätswerk A.G.). W latach trzydziestych do rady nadzorczej tego zakładu wchodził m.in. nadburmistrz Szczecina Werner Faber, a sprawa podniesienia przez ten zakład opłat za dostawę prąqu wzbudziła poważne protesty wśród odbiorców pomorskich $^{26}$.

Uwagi o rozwoju infrastruktury komunalnej miast pomorskich skłaniają do wniosku, że ton temu procesowi nadawały miasta duże i średnie. W drugiej połowie XIX stulecia zaczęly one szybciej inwestować w zakłady komunalne i taka tendencja utrzymała się po zakończeniu pierwszej wojny światowej. $\mathrm{W}$ dużych miastach prowincji już na przełomie XIX i XX stulecia stworzone zostały warunki do wykorzystywania energii elektrycznej. Miasta mniejsze i tzw. miasta karłowate $w$ ten proces wchodziły dopiero w latach dwudziestych $\mathrm{XX}$ w. Te ośrodki miejskie, które miały rozwiniętą infrastrukturę komunalną, dysponowały jednocześnie lepszymi warunkami bytowymi niemal automatycznie i stawały się bardziej atrakcyjnym celem dla migrującej ludności.

\section{NOWE UWARUNKOWANIA ROZWOJU PO 1933 R.}

Okres po 1933 r. zasadniczo różnił się od warunków rozwoju miast w okresie republiki weimarskiej. Główne zmiany w funkcjonowaniu władz gmin miejskich nastąpiły z początkiem 1934 r. na podstawie ustawy o ustroju gminnym (Gemeindeverfassungsgesetz) uchwalonej 15 XII 1933 r. Ustawa ta ujednoliciła system prawny i w praktyce likwidowała samorząd jako formę współudziału obywateli w życiu gminy. Na czele gminy miejskiej stawał burmistrz

${ }^{25}$ Szersze uwagi na temat elektryfikacji Pomorza zob. w: Paweł Gut, Rozwój energetyki na Pomorzu w latach 1880-1945, PZP, R. 31 (60): 2016, nr 3, s. 43-65; Romuald Nowakowski, Michał BALCERAK, Zarys historii elektryfikacji miast Pomorza Zachodniego na przełomie XIX i XX wieku, Maszyny elektryczne - Zeszyty Problemowe, t. 112: 2016, nr 4, s. 131-138.

${ }^{26}$ BA Berlin, Reichsministerium des Innern. Kommunalabteilung, Nr. 4226, s. 10. 
lub nadburmistrz, który faktycznie skupiał w swoim ręku zarówno władzę wykonawczą, jak i ustawodawczą. Rada przekształcała się w organ tylko opiniodawczy. W miastach dużych i średnich nadburmistrza lub burmistrza powoływał minister spraw wewnętrznych po zasięgnięciu opinii gauleitera. Także skarbnika powoływał ten sam minister. Kadencja władz gminy trwała 12 lat. Pozostałych urzędników gminy powoływał prezes rejencji. Organem opiniodawczym stawała się, oprócz wspomnianej rady miejskiej lub gminy, nowa instytucja tzw. doradców (Beiräte), których pośród zasłużonych mieszkańców miasta lub gminy mianował prezes rejencji ${ }^{27}$. Doradzali oni tylko w sprawach kierowanych do nich przez nadburmistrza lub burmistrza. Reforma ta ostatecznie odchodziła od modelu samorządu na szczeblu gminy mającego swoją genezę w zmianach jeszcze z połowy XIX stulecia i podporządkowywała go całkowicie partii narodowosocjalistycznej.

Sytuacja ekonomiczna miast pomorskich po 1933 r. była inna chociażby z tego powodu, że o rozwoju decydowały również czynniki inne niż ekonomiczne. Należy jednak pamiętać, że narodowi socjaliści nie mieli wypracowanej żadnej doktryny ekonomicznej i programu polityki gospodarczej. Ich poglądy sprowadzały się do tego, że państwo powinno kierować głównymi kierunkami rozwoju gospodarczego z jednoczesnym zachowaniem własności prywatnej. Jednym ze sposobów sterowania przez państwo gospodarką stawały się plany gospodarcze. Rząd jednak wyraźnie wskazywał, że jednym z głównych celów jego polityki stawała się walka z bezrobociem ${ }^{28}$. W opublikowanym w styczniu 1934 r. na łamach organu niemieckiego frontu pracy „Der Deutsche” planie odbudowy gospodarki pomorskiej jego autor E. Jarmer, pełniący funkcję radcy gospodarczego we władzach prowincji, podkreślał, że punkt ciężkości w tym procesie leżał w uzdrowieniu sytuacji gospodarczej na wsi i skierowania tam większej liczby bezrobotnych $z$ miast $^{29}$. Zatem rozwiązania problemów demograficznych i społecznych w miastach władze szukały poza nimi samymi.

Dążenie do kontrolowania życia gospodarczego wyrażało się również w usilnych zabiegach aparatu partyjnego o przejęcie kontroli nad organizacjami gospodarczymi typu izby przemysłowo-handlowe i wprowadzaniem

${ }^{27}$ Mieczysław Stelmach, Ustrój i finanse miejskie, [in:] Dzieje Szczecina, t. 3, s. 691; Paweł Gut, Ustrój, administracja i podzialy terytorialne pomorskich prowincji Prus w latach 1918-1939, ZH, t. 81: 2016, z. 3, s. 94.

${ }^{28}$ Czesław ŁuczaK, Dzieje gospodarcze Niemiec 1871-1945, Poznań 1984, s. 125; Wolfram Fischer, Deutsche Wirtschaftsgeschichte 1918-1945, Opladen 1968, s. 51. W odniesieniu do Pomorza por. Przemysław JACкоWsкI, Walka $z$ bezrobociem przez rozbudowe infrastruktury komunikacyjnej i melioracje na Pomorzu w świetle prasy szczecińskiej 1933-1939, PZP, R. 12 (41): 1997, nr 1-2, s. 129 n.

${ }^{29}$ BA Berlin, Reichslandbund. Pressearchiv, Nr. 2728, s. 184. 
przedstawicieli NSDAP do rad nadzorczych różnych spółek, zwłaszcza tych, które uznawano za strategiczne z punktu widzenia interesów państwa. Okazywało się wówczas, że znani przedstawiciele sfer gospodarczych nie mieli, zdaniem władz partyjnych, odpowiednich kwalifikacji do kierowania tymi organizacjami. Przykładem może być oświadczenie tychże władz, że nie były w stanie współpracować z przewodniczącym Krajowej Izby Rzemieślniczej dla Pomorza (Landeshandwerkskammer für Pommern) tylko z tego powodu, że był on do 1930 r. członkiem SPD. Nowe władze deklarowały jednak swoje poparcie dla rozwoju rzemiosła. Stąd pojawiały się propozycje tworzenia Kredytowych Związków Pomocowych (Kredithilfsverband) w poszczególnych miastach. Na Pomorzu już w 1934 r. takie związki powstały w kilku miastach, m.in. w Szczecinie, Stargardzie, Greifswaldzie, Nowogardzie, ale także w mniejszych miastach, takich jak Chociwel, Dobrzany czy Suchań ${ }^{30}$. Partia narodowosocjalistyczna miała również kłopoty z podporządkowaniem sobie Izby Przemysłowo-Handlowej w Szczecinie i postawieniem na jej czele swojego kandydata E. Fenglera. Problem ten został rozwiązany w momencie powołania nowego tworu pod nazwą Izby Gospodarczej Pomorza (Gauwirtschaftskammer für Pommern) będącego zresztą ekspozyturą Izby Gospodarczej Rzeszy (Reichswirtschaftskammer), który kontrolował właściwie wszystkie najważniejsze gałęzie gospodarcze (poza rolnictwem) i jednocześnie również izby przemysłowo-handlowe. Było rzeczą zrozumiałą samą przez się, że na jej czele znalazł się kandydat zaproponowany przez NSDAP ${ }^{31}$.

Ważną przesłankę dla rozwoju przemysłu u ujścia Odry i lokowania tu nowych zakładów w drugiej połowie lat trzydziestych stanowiły, jak wspomniałem, opinie kół wojskowych, w tym Inspekcji Zbrojeniowej Wehrmachtu i dowództwa II okręgu wojskowego (Wehrkreisgebiet II) obejmującego Meklemburgię i Pomorze. Dla nich obszar ujścia Odry stanowił bezpieczne miejsca do lokowania strategicznie ważnych z punktu widzenia zbrojeń inwestycji, gdyż znajdował się poza zasięgiem lotnictwa państw wrogich III Rzeszy: „Położenie Szczecina, głównego ośrodka handlu i przemysłu, w stosunku do stolicy Rzeszy jest szczególnie korzystne. [...] Istniejący tu przemysł zbrojeniowy

${ }^{30}$ LA Greifswald, Rep. 60, Nr. 1920, s. 105.

${ }^{31}$ BA Berlin, Reichswirtschaftsministerium, Nr. 13306, s. 34; Nr. 9749, s. 140-144. Szerzej o przejmowaniu kontroli nad życiem gospodarczym przez NSDAP pisali m.in.: Uwe SCHRöDER, „Zur faschistischen Kriegsvorbereitung im Regierungsbezirk Stettin von 1935 bis 1939”, Greifswald 1985 (maszynopis rozprawy doktorskiej w zbiorach Biblioteki Uniwersyteckiej w Greifswaldzie); Edward WŁODARCZYK, Zabiegi NSDAP o kontrole nad gospodarka Szczecina, [in:] Dzieje Szczecina, t. 3. s. 635-643. Por. również: Kacper Pencarski, Dwudziestolecie międzywojenne, druga wojna światowa (1918-1945), [in:] Dzieje Koszalina, t. 1: Do 1945 roku, red. Radosław GAZIŃsKi, Edward WŁodArCZyK, Koszalin 2015, s. 307. Ogólne uwagi o polityce III Rzeszy wobec rzemiosła por. również w: Heinrich August WinkLer, Der entbehrliche Stand. Zur Mittelstandspolitik im Dritten Reich, Archiv für Sozialgeschichte, Bd. 17: 1977, s. 7, 31. 
i inne zakłady przemysłowe są rozproszone na terenie okręgu, co zapewnia im bezpieczeństwo przed bombardowaniami lotniczymi, jak i wpływa korzystnie na procesy produkcyjne. Obszar najdalej odsunięty od zachodu należy do najlepiej zabezpieczonych przed nalotami terenów Rzeszy" ${ }^{32}$. W podobnie pozytywnym duchu komentowano znacznie portu szczecińskiego: „w tym okręgu wojskowym położony jest największy i najważniejszy port bałtycki. Spełnia on podstawową rolę zarówno w imporcie, jak i eksporcie, lecz liczy się głównie w przywozie rudy żelaza ze Skandynawii. To jest jego najistotniejszy militarno-gospodarczy wyznacznik"33.

Problem ożywienia gospodarki miast przez zamówienia wojskowe lub podporządkowywanie kołom wojskowym niektórych zakładów przemysłowych był widoczny w większych miastach. Dotyczyło to szczególnie Szczecina, Stralsundu, Greifswaldu i wybiórczo innych miast pomorskich. Zainteresowanie wojska dotyczyło niekiedy tylko części produkcji niektórych zakładów. Taka sytuacja nastąpiła w szczecińskiej fabryce chemicznej Union, w której wydzielono część pod nazwą Oderchemie G.m.b.H. i całkowicie podporządkowano wojsku ${ }^{34}$. Koła wojskowe oczekiwały od władz niektórych miast konkretnych działań. Tak się stało w 1936 r. w Kołobrzegu, kiedy zaproszono przedstawicieli magistratu na zamknięty wykład przygotowany przez dowództwo lotnictwa okręgu II o potrzebie budowy lotniska w Bagiczu. Takie postulaty płynęły zresztą również od naczelnego dowództwa Luftwaffe. Oczekiwano, że miasto dostarczy pewnej liczby robotników i zapewni połączenia telefoniczne. Tytułem odszkodowania za zajęty teren kasa miejska miała się wzbogacić o 140 tys. marek ${ }^{35}$.

Miasta portowe oczekiwały od władz centralnych wsparcia w ich planach rozwojowych. Właściwie dyskutowano tylko o planach rozwojowych portu szczecińskiego z uwagi na, jak wspomniałem, jego strategiczne położenie. $\mathrm{W}$ odniesieniu do pozostałych miast portowych podejmowano tylko niewielkie sporadyczne działania. Takim przykładem mogą być wymienione już starania o budowę lotniska w Kołobrzegu czy inwestycje w Ustce z uwagi na obsługiwanie przez ten port linii żeglugowej do Prus Wschodnich „Seedienst Ostpreußen". Przeładunki w portach rejencji koszalińskiej w 1938 r. wykazy-

${ }^{32}$ BA Berlin, Oberkommando der Wehrmacht. Filmsammlung Nr. 6018, opracowanie: Kriegsgeschichte der Rüstungsinspektion des Wehrkreises II. Opinię tę cytuje również: Hans Werner Rautenberg, Czas wielkich nadziei i klęski: w Trzeciej Rzeszy (do 1945 roku), [in:] Pomorze Zachodnie poprzez wieki, red. Jan M. PIsKorski, Szczecin 1999, s. 323-225.

${ }^{33}$ BA Berlin, Oberkommando der Wehrmacht. Filmsammlung, Nr. 13433 (Denkschrift über die wehrwirtschaftliche Bedeutung des Wehrkreis II - 1938).

${ }^{34}$ Ibid., Rechnungshof des Deutschen Reiches, Nr. 5583, s. 7.

${ }^{35}$ Ibid., Reichsministerium des Innern. Kommunalabteilung, Nr. 1703, s. 21-24. 
wały niewielką w porównaniu z latami dwudziestymi tendencję wzrostową i wynosiły one w Kołobrzegu 230 tys. ton, w Ustce 235 tys. ton i Darłowie 67 tys. ton, ale były to wielkości stosunkowo małe, świadczące o słabości portów i ich najbliższego zaplecza ${ }^{36}$. Warto jeszcze w tym kontekście zwrócić uwagę na swoistą rywalizację miast pomorskich. Władze rejencji koszalińskiej, podobnie jak magistrat tego miasta, wystąpiły z projektem budowy portu w Koszalinie. Według tych planów miasto powinno być połączone przez jezioro Jamno z Bałtykiem. Podkreślano, że nowy port w Koszalinie miałby lepsze warunki rozwoju niż porty w Darłowie i Ustce. Władze miasta w 1936 r. argumentowały, że obszar gospodarczy Koszalina potrzebuje portu. Przez ten obszar rozumiały ewentualne zaplecze portu rozciągające się po Piłę i Krzyż ${ }^{37}$. Plan ten jako nierealny odrzucono już XIX stuleciu i powracanie do niego świadczyło o braku rozeznania przez miejscowe koła gospodarcze i administracyjne.

W analizie funkcji miast portowych prowincji pomorskiej należy zwrócić uwagę na to, że władze niektórych z nich zdawały sobie sprawę ze zmiany charakteru i funkcji gospodarczych. W Greifswaldzie podkreślano, że miasto stawało się ośrodkiem przemysłowym i uniwersyteckim przy jednoczesnym zaniku funkcji w handlu morskim. W ocenie miejscowych władz Kołobrzeg stawał się coraz mocniej ośrodkiem leczniczo-wypoczynkowym. W $1936 \mathrm{r}$. władze miasta chciały, aby na podstawie Niemieckiej Ordynacji Gminnej (Deutsche Gemeinde Ordnung) z 1935 r. zmienić nazwę miasta na Seestadt Kolberg (miasto morskie). Nie aprobowano nazwy Ostseebad (uzdrowisko bałtyckie) Kolberg. Jednoznacznie nie można rozstrzygnąć, czy i kiedy miasto zmieniło nazwę, ale już w okresie wojny wysyłano pismo burmistrza Kołobrzegu z nadrukiem o treści „Das Ostseebad Kolberg”. W tym miejscu można także powołać się na zabiegi Kamienia Pomorskiego, którego władze w 1937 r. postulowały określanie miasta uzdrowiskiem (Kammin Bad), zgodnie z funkcją, jaką ono pełniło. Na kuracji w tym mieście przebywało bowiem w $1935 \mathrm{r}$. 410 pacjentów dorosłych i ponad 900 dzieci $^{38}$. Niezależnie od funkcjonowania armatora Seedienst Ostreußen swój charakter zmieniała także Ustka. Zwracał uwagę stan floty rybackiej w tym porcie, który w 1939 r. w porównaniu z rokiem 1920 zmniejszył się o 20 jednostek (z 65 do 45), oraz wzrastająca liczba kuracjuszy. W 1938 r. Ustka przyjęła ich ponad 3,5 tys. ${ }^{39}$

${ }^{36}$ K. PenCARski, „Gospodarka miast rejencji”, s. 412.

${ }^{37}$ BA Berlin, Reichsministerium des Innern. Kommunalabteilung, Nr. 1694, s. 368. Szersze rozważania por. w: E. WŁodARCZYK, Handel morski i porty, s. 20.

${ }^{38}$ BA Berlin, Reichsministerium des Innern. Kommunalabteilung, Nr. 1700, s. 33, 47; Nr. 1636, s. 23.

${ }^{39}$ Józef LindmajeR, W ramach państwa prusko-niemieckiego od początku XIX wieku do 1945 roku, [in:] Józef Lindmajer, Teresa Machura, Zygmunt Szultka, Dzieje Ustki, Słupsk 
W odniesieniu do dziejów miast pomorskich w latach trzydziestych rodzi się pytanie: czy militaryzacja Rzeszy odcisnęła piętno na ich charakterze? Miasta oprócz realizacji zamówień zbrojeniowych korzystały z rozbudowy miejscowych garnizonów i budowy nowych koszar. Według spisu z 1939 r. liczba mężczyzn będących w służbie wojskowej i robotniczej pokazuje, że prym wiodły miasta i powiaty będące „starymi” miastami garnizonowymi. Wyróżniał się tylko powiat uznamsko-woliński (w tym ważną rolę odgrywało Świnoujście), gdzie liczba osób będących w służbie wojskowej i robotniczej wynosiła 6243. Dużą liczbę osób w służbie wojskowej lub robotniczej miało Barth (4553). W Szczecinie służyły 3154 osoby, w Kołobrzegu 3077. Miasta dawnej rejencji stralsundzkiej były bardziej zmilitaryzowane, gdyż ponad 3100 osób na Rugii było w służbie wojskowej lub robotniczej. W Stralsundzie ponad 3600, w Greifswaldzie zaś prawie 3300 osób określano jako służących w wojsku lub służbie robotniczej. Nieco ponad 1900 osób odbywało służbę w Szczecinku, Białogardzie, Pile i Wałczu. Ponad 1500 takich osób odnotowywano w Koszalinie, Trzebiatowie, Demmin. Nieco poniżej 1500 w Lęborku. Zaskakuje mała liczba takich osób w powiatach nadgranicznych, tj. drawsko-pomorskim i bytowskim. Z kolei 1235 osób odnotowywanych dla powiatu choszczeńskiego rozlokowanych było w Brzezinach i Zwarkowie. Analiza danych dotyczących kobiet w służbie wojskowej i służbie pracy pokazuje ich najwyższą liczbę w Barth (1031). W Lęborku służyło 301 kobiet, w Bytowie zaś 17940. Zatem stopień militaryzacji miast pomorskich jako wysoki możemy odnosić tylko do niektórych z nich. Zaskakuje natomiast to, że miasta te nie leżały w pasie przygranicznym $z$ Polską.

W 1939 r. w hierarchii ważności miast pomorskich jako ważnych centrów życia ekonomicznego prowincji nie zaszły poważniejsze zmiany. Dominowała stolica prowincji Szczecin, który, zwłaszcza po utworzenie tzw. „Wielkiego Szczecina", skupiał na swoim obszarze ważne z punktu widzenia gospodarczego, ale i wojskowo-strategicznego zakłady przemysłowe z Hydriewerke A.G. Pölitz na czele. Utrzymywały swoją pozycję dwa główne ośrodki miejskie dawnej rejencji stralsundzkiej, tj. Stralsund i Greifswald. W rejencji koszalińskiej dominował jednak Słupsk, gdzie zlokalizowanych było ponad 40\% (40,1\%), tj. 395 podmiotów gospodarczych należących do Izby Przemysłowo-Handlowej rejencji koszalińskiej. Dwa inne duże miasta rejencji koszalińskiej, tj. Ko-

1985, s. 109, 114; Zygmunt Szopowski, Małe porty Pomorza Zachodniego do czasów drugiej wojny światowej, Poznań 1962, s. 126.

${ }^{40}$ Szczegółowe zestawienia zob. w: Dariusz K. Chојескі, Andrzej Giza, Edward WŁodarCZYк, Atlas Historyczny Pomorza Zachodniego, t. 2: Atlas gmin Pomorza Zachodniego w 1939 roku. Demografia - społeczeństwo - gospodarka, Szczecin 2017, arkusze (mapy) nr 4 i 6. 
szalin i Kołobrzeg, ustępowały jednak Słupskowi wyraźnie. W pierwszym z tych miast działało 249 firm należących do Izby, w drugim zaś 245 . Inne miasta rejencji znacznie odbiegały od tego poziomu. Przykładowo Bytów miał wówczas tylko 74 takie firmy. Dominującą w rejencji koszalińskiej pozycję Słupska potwierdzała także wielkość przeładunków towarów na kolei. Przeładowano ich w 1938 r. prawie 400 tys. ton, podczas gdy w portowym Kołobrzegu 270 tys. ton, a w Koszalinie tylko 200 tys. ton $^{41}$.

Jednym z ciekawszych nurtów dziejów miast pomorskich w omawianym okresie stawały się problemy budownictwa miejskiego. Z jednej strony władze magistrackie starały się kontrolować ten proces i powoływały, zwłaszcza w większych miastach, Urzędy Budowy Mieszkań (Wohnungsbauamt), z drugiej zaś udzielały zgody na prowadzenie działalności przez spółdzielnie mieszkaniowe i towarzystwa budowlane, które miały na celu zaspokajanie potrzeb różnych grup zawodowych. W Szczecinie działało pięć takich towarzystw, w Koszalinie w końcu lat dwudziestych zarejestrowanych było osiem towarzystw mieszkaniowych, w Słupsku dwa. Podobne istniały w kilku innych miastach, w tym w Greifswaldzie ${ }^{42}$. Pozytywną rolę w rozwoju budownictwa mieszkaniowego odegrało Szczecińskie Towarzystwo Mieszkaniowe (Stettiner Wohnstättengesellschaft m.b.H.). Działało ono od 1928 r. i wznosiło domy w Szczecinie, Drawsku, Grimmen, Sassnitz i Miastku. Były one zwykle przeznaczone dla urzędników. Po 1933 r. spółka nadal, mimo zmieniających się warunków, prowadziła swoją działalność. Najwięcej domów zbudowała w Szczecinie (np. w 1937 r. - 15), potem trzy domy w Saßnitz i po jednym w Drawsku, Grimmen i Miastku. W 1938 r. otrzymała także zlecenie na budowę domu z czterema mieszkaniami w Greifswaldzie ${ }^{43}$.

Lata 1933-1939 przyniosły w miastach pomorskich wyraźne ożywienie budownictwa mieszkaniowego. Wiązało się to m.in. ze znacznie zwiększonymi dotacjami państwowymi na ten cel. Rząd popierał takie budownictwo lokowane zwłaszcza na przedmieściach. Podejmujący budowę domków otrzy-

${ }^{41}$ Karl-Heinz Pegel, Stolp in Pommern - eine ostdeutsche Stadt: ein Buch über unsere pomersche Heimat, Lübeck 1977, s. 189, 196; Statistik des Deutschen Reiches, Bd. 576 (Die Seeschiffahrt im Jahre 1939).

${ }^{42}$ Mieczysław Stelmach, Miejska administracja budowlana i struktury organizacyjne budownictwa mieszkaniowego, [in:] Dzieje Szczecina, t. 3, s. 537-542; K. PenCarski, Dwudziestolecie międzywojenne, s. 330-333; Andrzej CzARniK, Lata republiki weimarskiej i III Rzeszy (1918-1945), [in:] Historia Stupska, red. Stanisław Gienszewski, Słupsk 1981, s. 348; Bernfried Lichtnau, Architektur in Greifswald von 1900 bis in die Gegenwart, [in:] Greifswald. Geschichte der Stadt, s. $490 \mathrm{n}$.

${ }^{43}$ BA Berlin, Rechnungshof des Deutschen Reiches, Nr. 6382 (Stettiner Wohnstättengesellschaft m.b.H. 1928/29-1941). 
mywali od państwa nisko oprocentowane kredyty i musieli również sami zaangażować się w jego realizację. To osadnictwo podmiejskie na Pomorzu organizowało Prowincjonalne Towarzystwo Osadnicze (Pommersche Heimstätte G.m.b.H). W jego statucie zapisano, że realizuje ono cele społeczne i ekonomiczne oraz ma ograniczyć migracje ludności do miast, ale powinno wspierać miasta w rozwiązywaniu ich problemów mieszkaniowych. Początkowy kapitał towarzystwa pomorskiego był wysoki i wynosił $4,1 \mathrm{mln}$ marek. Warto zwrócić uwagę na to, że częstym klientem towarzystwa stały się koła wojskowe. Budowano kolonie domków na ich potrzeby $\mathrm{w}$ miastach garnizonowych, przestrzegając zasady o wyższym standardzie mieszkan dla oficerów i niższym dla podoficerów. Towarzystwo realizowało także budowę domków dla kadry Hydriewerke Pölitz A.G. Nie unikano również innych zleceń, w tym na urządzenia komunalne ${ }^{44}$. Rozwój budownictwa mieszkaniowego w miastach pomorskich służył ustabilizowaniu sytuacji demograficzno-społecznej, która z kolei rzutowała pozytywnie na rozwój ekonomiczny miast.

\section{KONKLUZJE}

Przeprowadzone rozważania skłaniają do wysunięcia kilku wniosków:

1. Miasta prowincji pomorskiej w okresie dwudziestolecia międzywojennego swoim rozwojem potwierdzały specyfikę położenia ekonomicznego pozostałych wschodnich prowincji. Wyrażała się ona m.in. w wolniejszym tempie przemian niż $w$ całej gospodarce niemieckiej. Cała gospodarka Pomorza znalazła się na marginesie ogólnych trendów rozwojowych. Wiele gałęzi (zakładów) przemysłowych zlokalizowanych w miastach pomorskich nie weszło do organizacji gospodarczych ogólnoniemieckch monopolizujących rynek zamówień. Nieliczne wyjątki dotyczyły tylko niektórych branż przemysłowych zlokalizowanych w obszarze gospodarczym Szczecina.

2. Specyfika rozwoju miast pomorskich determinowana była $\mathrm{w}$ dużym stopniu procesami demograficznymi zachodzącymi w prowincji, $w$ tym głównie migracjami. Analizowane w artykule miasta w okresach 1925-1933 i 1933-1939 poza sporadycznymi przypadkami (dla lat 1925-1933 tylko Wałcz, dla następnego zaś Goleniów, Lębork, Pasewalk, Pyrzyce i Szczecin) nie odnotowywały jednak ujemnego bilansu migracyjnego i tym pozytywnie wyróżniały się na tle obrazu całej prowincji. Wszystkie miasta prowincji pomorskiej cechowała jednak wysoka stopa bezrobocia.

${ }^{44}$ Ibid., Rechnungshof des Deutschen Reiches, Nr. 6288, s. 1-2; Geheimes Staatsarchiv Preußischer Kulturbesitz Berlin-Dahlem, XV. Hauptabteilung, Rep. 60, Nr. 209 (Pommersche Heimstätte G.m.b.H. Provinzielle Treuhandstelle für Wohnungs- und Kleinsiedlungen. Geschäftsbericht 1936; Geschäftsbericht 1939). 
3. Biorąc pod uwagę typologizację miast pomorskich, należy stwierdzić, że niektóre z nich w porównaniu z XIX stuleciem zmieniły swoje funkcje. Niektóre jednak umocniły swój charakter jako ośrodki handlowo-komunikacyjne. Ponad 22,7\% ludności z pracy w handlu i komunikacji utrzymywało się w Stralsundzie, Pasewalku, Szczecinie, Stargardzie, Pile, Szczecinku i Słup$\mathrm{sku}^{45}$. Z kategorią miast portowo-handlowych pożegnał się Greifswald, stając się bardziej miastem przemysłowym. Charakter zmienił także Kołobrzeg. Wprawdzie funkcja portowa została utrzymana, ale miasto coraz mocniej zdominowane było przez świadczenie usług wypoczynkowo-leczniczych. Ewolucję w tym kierunku przechodziła Ustka. Do rangi ośrodka leczniczo-wypoczynkowego, z pewnymi zastrzeżeniami, możemy zaliczyć Kamień Pomorski, który w poprzednim okresie wyraźnie miał charakter ośrodka administracyjno-rzemieślniczo-handlowego. Najwięcej zmian dotyczyło jednak kategorii ośrodków komunikacyjnych. Poza tradycyjnymi węzłami komunikacyjnymi, tj. Pasewalkiem i Stargardem, znaczenie uzyskały Słupsk, Koszalin, Anklam, Szczecinek, Białogard, straciło je natomiast Miastko ${ }^{46}$. Należy jednak podkreślić, że nowe ośrodki komunikacyjne miały w przeważającej mierze znaczenie lokalne. W tym obrazie jako ważny ośrodek komunikacyjny wyróżniała się, włączona w 1938 r. do Pomorza, Piła, która w szerszym zakresie obsługiwała również połączenia międzynarodowe.

4. W okresie sprawowania rządów przez NSDAP miasta pomorskie nie otrzymały specjalnie ważnego impulsu dla swojego rozwoju. Tempo jego pozostawało nadal wolniejsze niż innych miast niemieckich.

Nadesłany 10 X 2017

Nadesłany po poprawkach recenzyjnych 6 III 2018

Zaakceptowany 25 III 2018

Prof. dr hab. Edward Włodarczyk

Instytut Historii i Stosunków Międzynarodowych

Uniwersytet Szczeciński

e-mail: ewlodarczyk@wp.pl; wlodar@univ.szczecin.pl

ORCID ID: 0000-0002-6699-4963

${ }^{45}$ Por. szerzej: D. Chojecki, A. Giza, E. WŁodarczyк, Atlas, karta (mapa) 23.

${ }^{46}$ Ibid. 
Conditions of the Economic Development of the Towns

in the Pomeranian Province in the Interwar Period

\section{Summary}

Key words: Pomeranian province, Pomeranian towns, urbanization, economic life, typology of towns

The article analyses the factors determining the development of the towns in the Pomeranian province in the years 1918-1939. The author maintained the typology of the towns from the period prior to WWI. The author also poses the question whether some of those towns changed the function they had played in the $19^{\text {th }}$ century.

The specific character of the development of Pomeranian towns in the period under discussion consisted in its new geopolitical and macroeconomic situation. After 1918 Western Pomerania became the frontier province. This situation determined the migration processes. The administrative authorities of the province indicated that it was also the reason for the economic stagnation. The author maintains that one may agree with the thesis about the migration processes being determined by the new political situation, but it should be rejected in reference to the economic development. The Pomeranian province after WWI found itself on the margin of Germany's economic life, which concerned both average-sized towns and the capital of the province - Szczecin. After the power in Germany had been taken over by the NSDAP and the military preparations had started, only some Pomeranian towns got the impulse to develop. The area which mostly took advantage of the policy was the territory of the so called great Szczecin. The pace of the development of the remaining towns was slower than in the case of other German towns and cities.

Some corrections should be introduced in the typology of Pomeranian towns for the discussed period. They concern mainly the weakening of the function of some ports such as Kołobrzeg and Greifswald. Some other towns started to play the role as communication centres important for the region - this group included Piła, which constituted a significant transport interchange of international importance, used mainly in the contacts with Poland. The deliberations included in the book indicate that economic changes in the towns of the Pomeranian province were very slow.

VORAUSSETZUNGEN FÜR DIE WIRTSCHAFTLICHE ENTWICKLUNG DER STÄDTE in Der Provinz Pommern in der Zeit ZWischen den WeltKriegen

\section{Zusammenfassung}

Schlüsselwörter: Provinz Pommern, pommersche Städte, Urbanisierung, Wirtschaftsleben, Typologisierung von Städten

Der Artikel analysiert die Faktoren, die die Entwicklung der Städte in der Provinz Pommern in den Jahren 1918-1939 bedingten. Bei der Analyse wird die Typologisie- 
rung von Städten aus der Zeit vor dem Ersten Weltkrieg beibehalten. Zugleich wird die Frage gestellt: Haben einige dieser Städte ihre Funktion geändert, die sie im 19. Jahrhundert erfüllten?

Die Besonderheit in der Entwicklung der pommerschen Städte im besprochenen Zeitraum bestand unter anderem darin, dass sie sich in einer neuen geopolitischen und makroökonomischen Lage befanden. Denn Westpommern wurde nach $1918 \mathrm{zu}$ einer Grenzprovinz. Diese Situation beeinflusste in hohem Maß die Migrationsprozesse. Die Verwaltung der Provinz verwies darauf, dass sie auch der Grund für die wirtschaftliche Stagnation sei. Auch wenn man der These von der Beeinflussung der Migrationsprozesse durch die neue politische Situation zustimmen kann, so ist sie als Grund für die wirtschaftliche Entwicklung zu verwerfen. Die Provinz Pommern befand sich nach dem Ersten Weltkrieg am Rande des deutschen Wirtschaftslebens. Das betraf sowohl die mittelgroßen Städte in Pommern wie auch die Hauptstadt der Provinz, also Stettin. Nach der Machtübernahme der NSDAP und dem Beginn von militärischen Vorbereitungen ergaben sich nur für einige Städte in Pommern neue Entwicklungsmöglichkeiten. Hauptsächlich profitierte davon das Gebiet des sog. Groß-Stettin. Das Entwicklungstempo der übrigen Städte blieb weiterhin langsamer als das von anderen deutschen Städten.

Bei der Typologisierung von pommerschen Städten für den besprochenen Zeitraum sollten gewisse Korrekturen vorgenommen werden. Sie betreffen vor allem den Rückgang der Bedeutung einiger als Hafen- und Handelsstädte, hauptsächlich Kolberg und Greifswald. Eine Gruppe anderer Städte gewann als Verkehrszentren an Bedeutung, aber nur als Verkehrszentren von regionalem Rang. Positiv hob sich in dieser Gruppe von Städten Schneidemühl hervor, das 1938 der Provinz angeschlossen wurde und das ein wichtiger Verkehrsknotenpunkt für internationale Verbindungen wurde, hauptsächlich mit Polen. Die angestellten Überlegungen lassen auf ein langsames Tempo der wirtschaftlichen Veränderungen in den Städten der Provinz Posen schließen, manchmal gar auf eine Stagnation.

\section{Bibliografia}

Becker, Bert, and Kyra T. Inachin, eds. Pommern zwischen Zäsur und Kontinuität: 1918, 1933, 1945, 1989. Schwerin: Thomas Helms Verlag, 1999.

Chojecki, Dariusz K., Andrzej Giza, Edward Włodarczyk. Atlas gmin Pomorza Zachodniego w 1939 roku: Demografia - społeczeństwo - gospodarka. Szczecin: Wydawnictwo Naukowe Uniwersytetu Szczecińskiego, 2017.

Czarnik, Andrzej. “Lata republiki weimarskiej i III Rzeszy (1918-1945).” In Historia Stupska, edited by Stanisław Gierszewski, 329-401. Poznań: Wydawnictwo Poznańskie, 1981.

Dopierała, Bogdan. Ekonomiczne i demograficzne problemy Pomorza Zachodniego $w$ świetle niemieckich materiałów źródłowych $z$ lat 1926-1932. Poznań: Instytut Zachodni, 1959.

Dopierała, Bogdan. Kryzys gospodarki morskiej Szczecina w latach 1919-1939: Studia z dziejów portu szczecińskiego na tle niemieckie i polskiej polityki morskiej. Poznań: Wydawnictwo Poznańskie, 1963. 
Gut, Paweł. “Rozwój energetyki na Pomorzu w latach 1880-1945.” Przegląd Zachodniopomorski 31/3 (2016): 43-65.

Gut, Paweł. "Ustrój, administracja i podziały terytorialne pomorskich prowincji Prus w latach 1918-1939." Zapiski Historyczne 81/3 (2016): 73-104.

Hietala, Marjatta. Services and Urbanization at the Turn of Century: The Diffusion of Innovations. Helsinki: Finnish Historical Society, 1987.

Jackowski, Przemysław. "Walka z bezrobociem przez rozbudowę infrastruktury komunikacyjnej i melioracje na Pomorzu w świetle prasy szczecińskiej 1933-1939.” Przeglad Zachodniopomorski 12/1-2 (1997): 129-165.

Kiesewetter, Hubert. "Industrialisierung und ausgebliebende Industrialisierung in Preußen." In Pommern im 19. Jahrhundert. Staatliche und gesellschaftliche Entwicklung in vergleichender Perspektive, edited by Thomas Stamm-Kuhlmann, 233-250. Köln: Böhlau, 2007.

Lichtnau, Bernfried. "Architektur in Greifswald von 1900 bis in die Gegenwart.” In Greifswald: Geschichte der Stadt, edited by Horst Wernicke, 475-510. Schwerin: Thomas Helms Verlag, 2000.

Lindmajer, Józef. "Bytów w okresie republiki weimarskiej i rządów faszystowskich (1918-1945)." In Historia Bytowa, edited by Zygmunt Szultka, 260-353. Bytów: Wydział Oświaty, Kultury, Sportu i Turystyki Urzędu Miejskiego, 1998.

Lindmajer, Józef. "Przyczynek do monografii gospodarczej małych rzek Pomorza Zachodniego na przykładzie Wieprzy w trzecim ćwierćwieczu XIX stulecia.” Rocznik Koszaliński 27 (1997): 35-53.

Lindmajer, Józef. "W ramach państwa prusko-niemieckiego od początku XIX wieku do 1945 roku." In Józef Lindmajer, Teresa Machura and Zygmunt Szultka, Dzieje Ustki, 61-122. Słupsk: PTH Oddział w Słupsku, 1985.

Łuczak, Czesław. Dzieje gospodarcze Niemiec: 1871-1945. Poznań: Wydawnictwo Naukowe UAM, 1984.

Matzerath, Horst. Urbanisierung in Preußen 1815-1914. Stuttgart: W. Kohlhammer: Deutscher Gemeindeverlag, 1985.

Mielcarek, Andrzej. Transport drogowy, wodny i kolejowy w gospodarce prowincji pomorskiej w latach 1815-1914. Szczecin: Wydawnictwo Naukowe Uniwersytetu Szczecińskiego, 2000.

Mottek, Hans, Walter Becker and Alfred Schröter. Wirtschaftsgeschichte Deutschlands: Ein Grundriss, 3: Von der Zeit der Bismarckschen Reichsgründung 1871 bis zur Niederlage des faschistischen deutschen Imperialismus 1945. Berlin: VEB Deutscher Verlag der Wissenschaften, 1975.

Nerée, Donate v. "Industrie und Handwerk in Pommern in der Weimarer Republik." In Pommern. Geschichte - Kultur - Wissenschaft. Pommern im Reich und in Europa, edited by Horst Wernicke and Ralf-Gunnar Werlich, 363-377. Greifswald: Ernst-Moritz-Arndt-Universität, 1996.

Nowakowski, Romuald, and Michał Balcerak. "Zarys historii elektryfikacji miast Pomorza Zachodniego na przełomie XIX i XX wieku." Maszyny Elektryczne - Zeszyty Problemowe 112/4 (2016): 131-138.

Pagel, Karl-Heinz. Stolp in Pommern - eine ostdeutsche Stadt: Ein Buch über unsere pommersche Heimat. Lübeck: Heimatkreises Stolp, 1977. 
Pencarski, Kacper. "Dwudziestolecie międzywojenne, druga wojna światowa (19181945).” In Dzieje Koszalina, 1: Do 1945 roku, edited by Radosław Gaziński and Edward Włodarczyk, 287-349. Koszalin: Koszalińska Biblioteka Publiczna, 2016.

Rautenberg, Hans-Werner. "Czas wielkich nadziei i klęski: W Trzeciej Rzeszy (do 1945 r.)." In Pomorze Zachodnie poprzez wieki, edited by Jan M. Piskorski, 301-336. Szczecin: Zamek Książąt Pomorskich, 1999.

Reulecke, Jürgen. "Städtische Finanzprobleme und Kriegswohlfahrtspflege im Ersten Weltkrieg unter besonderer Berücksichtigung der Stadt Barmen." Zeitschrift für Stadtgeschichte, Stadtsozologie und Denkmalplege 2/1 (1975): 48-80.

Salmonowicz, Stanisław. "Podziały terytorialne i organizacja administracji w województwie pomorskim (1920-1939).” In Historia Pomorza, 5: (1918-1939): Województwo pomorskie i Wolne Miasto Gdańsk, p. 1: Ustrój, społeczeństwo, gospodar$k a$, edited by Szczepan Wierzchosławski and Przemysław Olstowski, 70-87. Toruń: Wydawnictwo Towarzystwa Naukowego w Toruniu, 2015.

Scherer, Franz. "Stadtgeschichte von 1815 bis 1918." In Greifswald: Geschichte der Stadt, edited by Horst Wernicke, 103-120. Schwerin: Thomas Helms Verlag, 2000.

Stelmach, Mieczysław. "Geneza 'Wielkiego Szczecina.' In Dzieje Szczecina, 3: 18061945, edited by Bogdan Wachowiak, 542-553. Szczecin: Wydawnictwo „13 Muz”, 1994.

Stelmach, Mieczysław. "Miejska administracja budowlana i struktury organizacyjne budownictwa mieszkaniowego." In Dzieje Szczecina, 3: 1806-1945, edited by Bogdan Wachowiak, 537-542. Szczecin: Wydawnictwo „13 Muz”, 1994.

Stelmach, Mieczysław. "Ustrój i finanse miejskie." In Dzieje Szczecina, 3: 1806-1945, edited by Bogdan Wachowiak, 686-703. Szczecin: Wydawnictwo „13 Muz”, 1994.

Szopowski, Zygmunt. Małe porty Pomorza Zachodniego w okresie do drugiej wojny światowej. Poznań: Państwowe Wydawnictwo Naukowe, 1962.

Szudra, Dariusz. Ludność pruskiej prowincji Pomorze: Przemiany w ruchu naturalnym i migracyjnym w latach 1914-1939. Szczecin: Wydawnictwo Naukowe Uniwersytetu Szczecińskiego, 2005.

Urbaniak, Miron. Miejskie zakłady przemysłowe Wielkiego Księstwa Poznańskiego: Gazownie, 1: Zarys dziejów. Łódź: „Księży Młyn” Dom Wydawniczy Michał Koliński, 2011.

Wernicke, Horst, ed. Greifswald: Geschichte der Stadt. Schwerin: Thomas Helms Verlag, 2000.

Winkler, Heinrich A. "Der entbehrliche Stand. Zur Mittelstandspolitik im Dritten Reich.” Archiv für Sozialgeschichte 17 (1977): 1-40.

Witt, Werner, ed. Wirtschafts- und verkehrsgeographischer Atlas von Pommern. Stettin: Ostsee - Druck und Verlag A.-G., 1934.

Włodarczyk, Edward. "Handel morski i porty Pomorza Zachodniego w pierwszych latach II wojny światowej.” Zapiski Historyczne 55/2-3 (1990): 17-39.

Włodarczyk, Edward. Pomorze Zachodnie w okresie od traktatu wersalskiego po klęske III Rzeszy w 1945 r. Poznań: Wydawnictwo Poznańskie, Gdańsk: Zrzeszenie Kaszubsko-Pomorskie, 2006.

Włodarczyk, Edward. "Powstanie Szczecińsko-Pruskiej Wspólnoty Portowej w 1923 roku.” Przegląd Zachodniopomorski 7/3 (1992): 29-47. 
Włodarczyk, Edward. "Rozwój urbanistyczny miast pomorskich i ich gospodarka komunalna.” In Historia Pomorza, 4: (1850-1918), p. 1: Ustrój, gospodarka, społeczeństwo, edited by Stanisław Salmonowicz, 467-473. Toruń: Wydawnictwo Towarzystwa Naukowego, 2000.

Włodarczyk, Edward. “Tendencje rozwojowe miast prowincji zachodniopomorskiej w latach 1850-1918." Zapiski Historyczne 63/1 (1998): 93-121.

Włodarczyk, Edward. "Wpływ zmian granicznych na wschodzie Niemiec po pierwszej wojnie światowej na gospodarkę prowincji nadgranicznych w ocenie Andreasa Hessego." Przeglad Zachodniopomorski 19/3 (2004): 47-58.

Włodarczyk, Edward. "Zabiegi NSDAP o kontrolę nad gospodarką Szczecina." In Dzieje Szczecina, 3: 1806-1945, edited by Bogdan Wachowiak, 635-643. Szczecin: Wydawnictwo „13 Muz”, 1994.

Włodarczyk, Edward. “Życie gospodarcze” In Dzieje Szczecina, 3: 1806-1945, edited by Bogdan Wachowiak, 568-684. Szczecin: Wydawnictwo „13 Muz”, 1994.

Wojciechowski, Mieczysław. Powrót Pomorza do Polski: 1918-1920. Warszawa, Poznań: Państwowe Wydawnictwo Naukowe, 1981.

Wolfram Fischer: Deutsche Wirtschaftspolitik 1918-1945. Opladen: Leske \& Budrich, 1968.

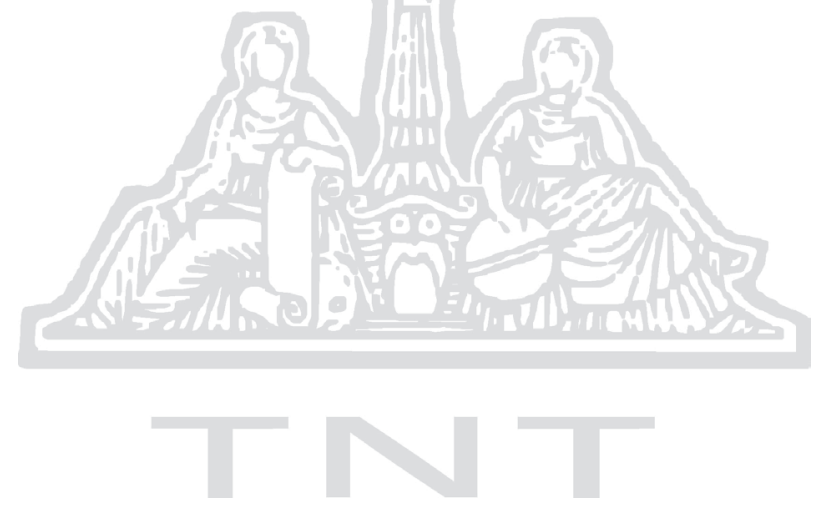

